\title{
Activity and Expression Pattern of NF- $\nsim$ B /P65 in Peripheral Blood from Hepatocellular Carcinoma Patients - Link to Hypoxia Inducible Factor $-1 \alpha$
}

\author{
Hanaa Hibishy Gaballah" ${ }^{1 *}$, Soha Said Zakaria' ${ }^{1}$, Saber Abdelrahman Ismail ${ }^{2}$
}

\begin{abstract}
Background: Hepatocellular carcinoma is a complex and heterogeneous tumor with poor prognosis due to frequent intrahepatic spread and extrahepatic metastasis. The molecular mechanisms underlying HCC pathogenesis still remain obscure. Objectives: We aimed to investigate the abundance and the DNA binding activity of nuclear factor kappa B/p65 subunit in peripheral blood mononuclear cells from patients with $\mathrm{HCC}$ and to assess its prognostic significance and association with hypoxia inducible factor one alpha (HIF-1 $\alpha)$ in blood. Subjects and methods: This study was carried out on 40 patients classified equally into liver cirrhosis (group I) and HCC (group II), in addition to 20 healthy volunteers (group III). All groups were subjected to measurement of NF- $x$ B /P65 subunit expression levels by real time-PCR, and DNA binding activity was evaluated by transcription factor binding immunoassay. Serum HIF-1 $\alpha$ levels were estimated by enzyme-linked immunosorbent assay (ELISA). Significant increase of both the expression level and DNA binding activity of NF- $\varkappa$ B /P65 subunit together with serum HIF-1 alpha levels was noted in HCC patients compared to liver cirrhosis and control subjects, with significant positive correlation with parameters for bad prognosis of HCC. In conclusion, NF- $\varkappa$ B signaling is activated in HCC and associated with disease prognosis and with high circulating levels of HIF-1 alpha.
\end{abstract}

Keywords: HCC - liver cirrhosis, NF- $\varkappa$ B - hypoxia inducible factor one alpha - binding activity

Asian Pac J Cancer Prev, 15 (16), 6911-6917

\section{Introduction}

Hepatocellular carcinoma (HCC) is the most common liver malignancy and rates fifth in incidence and third in mortality in the world. In Egypt, the incidence rate of HCC was doubled in the past 10 years (Abdelaziz et al., 2014). Multiple risk factors are associated with HCC disease etiology, with the highest incidence in patients with chronic hepatitis B virus (HBV) and hepatitis $\mathrm{C}$ virus (HCV) (Su et al., 2013), although other factors such as genetic makeup and environmental exposure are involved (Gao et al., 2012).

Nuclear factor $-\chi \mathrm{B}$ was originally identified as a nuclear factor specific to B cells bound to the B site of the kappalight chain gene enhancer. However, NF- $x \mathrm{~B}$ was later found to be expressed in other cell types such as the liver epithelium, where it regulates hepatic cell proliferation and survival during regeneration and development (Tiwari et al., 2013). NF- $x$ B controls the expression of genes involved in the regulation of fundamental processes such as the immune response, cell adhesion, oxidative stress and cell survival (Hung et al., 2008).

$\mathrm{NF}-\mathrm{kB}$ plays a crucial role in bridging the action of growth factors and inflammation to hepatic oncogenesis (Beale et al., 2008), its constitutive activation is one of the early key events involved in neoplastic progression of the liver (Luedde et al., 2011)

NF- $x$ B activity comprises homo- or heterodimers formed by members of the (Reticulo Endotheliosis) Rel/ NF- $x$ B family of transcription factors. The functional specificity and selectivity of the NF- $x \mathrm{~B}$ response arise primarily from the binding of Rel/NF- $x \mathrm{~B}$ complexes to specific DNA regulatory sites ( $\varkappa \mathrm{B}$ sites) of target genes in different cell types (Escarcega et al., 2007).

In humans, there are 5 subunits of this family of proteins: RelA (also called p65), NFxB1 (also called p50), NFxB2 (also called p52), RelB and RelC (GonzalezRamos et al., 2012). NF- $x$ B is kept inactive in the cytoplasm by binding to one of the inhibitory proteins called I $\alpha$ B- $\alpha, \mathrm{I} \varkappa \mathrm{B}-\beta, \mathrm{I} \chi \mathrm{B}-\varepsilon, \mathrm{p} 105$ and p100. As a result of the phosphorylation and subsequent degradation of the inhibitory subunits, NF- $x$ B translocates to the nucleus, binds to $\varkappa \mathrm{B}$ sites and regulates target genes. Due to its strong transcriptional activity, the p65 subunit of NF$x \mathrm{~B}(\mathrm{NF}-x \mathrm{~B} / \mathrm{p} 65)$ is responsible for most of NF- $x \mathrm{~B}$ 's transcriptional activity (van Loo and Beyaert 2011).

Hypoxia-inducible factors (HIFs) are essential mediators of the cellular oxygen-signaling pathway. They are heterodimeric transcription factors consisting of an oxygen-sensitive alpha subunit (HIF- $\alpha)$ and a 
constitutive beta subunit (HIF- $\beta$ ) that facilitate both oxygen delivery and adaptation to oxygen deprivation. Hypoxia-inducible factors regulate multiple aspects of tumorigenesis, including angiogenesis, proliferation, metabolism, metastasis, differentiation, and response to radiation therapy (Mimeault et al., 2013).

$\mathrm{NF}-\varkappa \mathrm{B}$ and HIF- $1 \alpha$ are of major importance for disease states associated with low-oxygen tension, such as cancer .A cross-talk between the NF- $x$ B pathway and the HIF pathway has been recently assumed, as NF $x$ B might be involved in redox-sensitive induction of the HIF-1 through binding at a distinct element in its proximal promoter. Moreover, HIF-1 itself may contribute to the activation of the NF- $x$ B pathway (Gorlach et al., 2008).

However, the interplay between NF $x$ B/P65, HIF-1 in hepatocellular carcinoma has not been fully elucidated yet. Therefore, we aimed to assess the expression pattern and the DNA binding activity of NFxB/P65 subunit in the peripheral blood of patients with $\mathrm{HCC}$ and to evaluate their relevance to the circulating levels of HIF-1 in order to gain biological insight on the molecular mechanisms of hepatic carcinogenesis, which may be beneficial in the early diagnosis and treatment of unresectable human HCCs.

\section{Subjects and Methods}

This study was carried out on 40 patients presented to Tropical Medicine Department, Tanta University Hospital and its Outpatient Clinics as well as 20 healthy volunteers represented as control group. They were classified as follows: Group I: included 20 patients with liver cirrhosis (13 males \& 7 females), aged 45 to 61 years with no radiological evidence for hepatic focal lesions. Group II: included 20 patients with HCC (15males \& 5 females) aged 49 to 63 years. Diagnosis was performed by the appropriate imaging characteristics according to The American Association for the Study of Liver Diseases (AASLD) practice guidelines (Bruix and Sherman 2005). The Milan criteria was defined as the presence of a tumor $5 \mathrm{~cm}$ or less in diameter in patients with single $\mathrm{HCC}$ or no more than 3 tumor nodules, each $3 \mathrm{~cm}$ or less in diameter, in patients with multiple tumors, and no extrahepatic metastasis and no major hepatic vessel invasion (Lei JY et al., 2013). Group III: included 20 healthy subjects (12 males \& 8 females) aged 48 to 60 years.

Patients with history of previous resection of HCC, or interferon based therapy for $\mathrm{HCV}$ or who have metastatic liver disease or with extra-hepatic metastasis were excluded from the study. Informed written consent was obtained from all participants. Approval was obtained from the Local Research Ethics Committee, Tanta University. Patients and controls were subjected to full history taking, thorough clinical examination and abdominal ultrasonography.

\section{Blood sample collection}

After 12 hours of overnight fasting, $7 \mathrm{ml}$ of venous blood samples were taken from every investigated subject, transferred slowly into a dry sterile centrifuge tube, allowed to clot at room temperature, centrifuged at 2000 rpm for 10 minutes and serum was separated and stored at $-70^{\circ} \mathrm{C}$ until the time of analysis.

\section{Laboratory investigations included}

i) Routine investigations: blood sugar, blood urea and creatinine, complete blood picture, complete urine and stool analysis; ii) Hepatitis viral marker including anti$\mathrm{HCV}$ and anti-HBV were detected by ELISA(Wilkins T et al., 2010); iii) Liver function tests including: serum alanine aminotransferase (ALT), serum aspartate aminotransferase (AST), serum albumin, prothrombin time and serum bilirubin; $i v$ ) Estimation of serum alpha fetoprotein level (Johnson, 2001); v) Quantitative Determination of circulating HIF-1 $\alpha$ level: The levels of serum HIF- $1 \alpha$ were determined by an enzyme-linked immunosorbent assay (ELISA) using a commercially available kit (R\&D Systems, Minneapolis, MN 55413, USA) according to the manufacturer's instructions. Concentrations were calculated using a standard curve generated with specific standards provided by the manufacturer; vi) Expression of NFxB/p65 gene in peripheral blood mononuclear cells (PBMCs) was detected by using Real-time PCR (RT-PCR).

Preparation of Peripheral blood mononuclear cells (PBMCs): PBMCs were prepared by density gradient centrifugation using Ficoll-Hypaque (Pharmacia, Uppsala, Sweden). Briefly, heparinised blood was carefully layered on Ficoll, and PBMC were harvested from the white interphase after centrifugation for 30 minutes at $400 \mathrm{~g}$, at room temperature and washed with phosphate buffered saline (PBS). The PBMCs samples were stored at $-80^{\circ} \mathrm{C}$ till the samples were further processed for RNA isolation.

Real-time PCR: Total RNA from PBMC was prepared using Trizol reagent (Gibco BRL Life Technologies) according to the manufacturer's instructions. The integrity of total RNA was checked by electrophoresis through $1 \%$ agarose gel. RNA samples were then stored at $-80^{\circ} \mathrm{C}$. cDNA synthesis was performed using the RevertAid H Minus First Strand cDNA Synthesis kit (\#K1632, Thermo Scientific Fermentas, St. Leon-Ro, Germany) according to the manufacturer's instructions. Real-time PCR was carried out with single stranded cDNAs. PCR reactions were performed using Power SYBR Green PCR Master Mix and 7500 Fast Real-Time PCR System (Applied Biosystems, CA, USA). Primer sequences specific for the NFxB /p65 (No: NM_021975.3) are : Fwd: 5'-ATCTGCCGAGTGAACCGAAACT-3'; and Rev: 5'-CCAGCCTGGTCCCGTGAAA-3' (Sun W et al., 2012); $\beta$-actin (No:NM_001101.3): Fwd: 5'TGGCATTGCCGACAGGATGCAGAA-3', Rev:5' CTCGTCATACTCCTGCTTGCTGAT -3'. $\beta$-actin primers were used as an internal control. Real-Time PCR was carried out, in duplicate, by 40 cycles of $95^{\circ} \mathrm{C}$ for $10 \mathrm{sec}$ and $60^{\circ} \mathrm{C}$ for $1 \mathrm{~min}$. Comparative $\mathrm{Ct}$ (threshold cycle) method was used to determine relative amounts of the products, according to the Applied Biosystems instructions. Conventional PCR was performed with the DreamTaq polymerase (\#EP0701, Thermo Scientific Fermentas, St. Leon-Ro, Germany). All expression data were normalized by dividing the target amount by the amount of $\beta$-actin used as internal control for each sample. 
$N F \varkappa B$ activation was examined by using transcription factor binding assay kit as follows:

Isolation of nuclear proteins Nuclear proteins were isolated from PBMCs extract using Nuclear Extract kit (Cat\#40010,Active Motif, Carlsbad, CA, USA) according to the protocol of the manufacturer. Briefly, the sample was placed in $0.8 \mathrm{~mL}$ of ice-cold hypotonic buffer [10mmol/L HEPES (pH7.9), $10 \mathrm{~mL} \mathrm{KCL,} 0.1 \mathrm{mmol} / \mathrm{L}$ EDTA, 0.1 $\mathrm{mmol} / \mathrm{L}$ ethylene glycol tetraacetic acid, $1 \mathrm{mmol} / \mathrm{L}$ DTT; Protease inhibitors (aprotinin, pepstatin and leupeptin, $10 \mathrm{mg} / \mathrm{L}$ each). The homogenates were incubated on ice for 20 mins, vortexed for 20 s after adding $50 \mu \mathrm{L}$ of $10 \%$ Nonidet $\mathrm{p}-40$, and then centrifuged for 1 minute at $4^{\circ} \mathrm{C}$ in an Eppendorf centrifuge. Supernatants were decanted, the nuclear pellets after a single wash with hypotonic buffer without Nonidet p-40 were suspended in an ice-cold hypertonic buffer (20 mmol/L HEPES ( $\mathrm{pH}$ 7.9), $0.4 \mathrm{~mol} / \mathrm{L} \mathrm{NaCL}, 1 \mathrm{mmol} / \mathrm{L}$ EDTA, $1 \mathrm{mmol} / \mathrm{L} \mathrm{DTT}$; Protease inhibitors), incubated on ice for $30 \mathrm{mins}$ at $4^{\circ} \mathrm{C}$ , mixed frequently and centrifuged for 15 mins at $4^{\circ} \mathrm{C}$. The supernatants were collected as nuclear extracts and stored at $-70^{\circ} \mathrm{C}$ (Gong JP et al., 2002). Concentrations of total proteins in the samples were determined according to the method of Bradford (\#Cat no.500-0006, Bio-Rad Protein Assay) (Bradford, M. 1976).

Evaluation of NF-kB/p65 DNA-binding activity $\mathrm{NF}$ B/p65 DNA-binding activity was evaluated using the ELISA-based TransAM ${ }^{\mathrm{TM}} \mathrm{NF}$ B/p65 protein assay (\#Cat no. 40096, Active Motif, Carlsbad, CA, USA), following the protocol of the manufacturer. In this commercial kit, a duplexed NF- $x \mathrm{~B}$ oligonucleotide containing a $x \mathrm{~B}$ consensus sequence is attached to the surface of 96-well plates. Activated NF- $x \mathrm{~B}$ dimers in $20 \mu \mathrm{g}$ nuclear extract bound to the attached oligonucleotide is specifically and quantitatively detected by subsequent incubation with antibodies against the activated forms of NF $x$ B/p65 followed by an enzyme-linked (horseradish peroxidase) secondary antibody for colorimetric scoring (Van Laere SJ et al., 2006). The absorbance was measured on an ELISA reader at $450 \mathrm{~nm}$ with a reference wavelength of $655 \mathrm{~nm}$.

\section{Statistical analysis}

The data were analyzed using statistical package for the social science (SPSS) version 20.0 software (SPSS Inc., Chicago, IL, USA). Quantitative data were expressed as mean \pm Standard deviation. Qualitative data expressed as number and percentage and analyzed by Chi -square test (X2). Multiple comparisons were performed by oneway analysis of variance (ANOVA) followed by Tukey's post-hoc test for multiple comparisons. Correlations were analyzed using the Pearson test.

\section{Results}

The demographic data and associated risk factors are demonstrated in Table 1 . There were no significant differences in age, sex and associated risk factors between the liver cirrhosis and HCC groups. Table 2 shows the clinical and ultrasonographic characteristics of the studied groups. There was no significant difference in portal vein diameter between cirrhotic and HCC patients, while portal vein thrombosis (PVT) was found in $3(15 \%)$ cirrhotic patients and $4(20 \%)$ HCC patients. Concomitantly, there was significant difference as regards MELD score between cirrhotic and HCC groups (p-value <0.05). Regarding Milan Criteria, 9 (45\%) HCC patients lay within, while $11(55 \%)$ patients lay beyond the criteria. Tumor size was $<3 \mathrm{~cm}$ in $8(40 \%)$ patients, while $12(60 \%)$ patients had tumor size $>3 \mathrm{~cm}$. Also, $9(45 \%)$ patients had single tumor while multiple tumors were demonstrated in 11 (55\%) HCC patients. Portal vein invasion was found in 4 (20\%) HCC patients.

Laboratory biochemical findings for the studied groups are demonstrated in Table 3. Hepatic profile namely ALT, AST, serum albumin, prothrombin activity, international normalized ratio (INR) and direct bilirubin showed statistically significant differences between patients and control groups, with having statistically significant higher levels in HCC group compared to liver cirrhosis group.

On the other hand, there were no statistically significant differences between the studied groups as regards hemoglobin \%, or total lecuocytic count.

The mRNA expression levels of NF-KB/p65 subunit

Table 1. Demographic and Associated Risk Factors in The Patients Groups

\begin{tabular}{|c|c|c|c|c|c|}
\hline & & $\begin{array}{l}\text { Group I, } \\
\text { Liver } \\
\text { cirrhosis } \\
(\text { No. }=20)\end{array}$ & $\begin{array}{c}\text { Group II, } \\
\text { Hepatocellular } \\
\text { carcinoma } \\
(\text { No. }=20)\end{array}$ & $\mathrm{F} / \mathrm{X}^{2}$ & p-value \\
\hline \multicolumn{2}{|l|}{ Age } & $52.8 \pm 7.8$ & $55.6 \pm 7.6$ & $\mathrm{~F}=0.258$ & 0.117 \\
\hline \multirow[t]{2}{*}{ Sex } & Male & $13(65 \%)$ & $15(75 \%)$ & $X^{2}=0.599$ & 0.362 \\
\hline & Female & $7(35 \%)$ & $5(25 \%)$ & & \\
\hline \multicolumn{6}{|c|}{ HCV antibodies only } \\
\hline & Positive & $16(80 \%)$ & $13(65 \%)$ & $\mathrm{X}^{2}=1.889$ & 0.028 \\
\hline & Negative & $4(20 \%)$ & $7(35 \%)$ & & \\
\hline \multicolumn{6}{|c|}{ HCV\&HBV antibodies } \\
\hline & Positive & $4(20 \%)$ & $7(35 \%)$ & $\mathrm{X}^{2}=1.132$ & 0.288 \\
\hline & Negative & $16(80 \%)$ & $13(65 \%)$ & & \\
\hline
\end{tabular}

*Group I: patients with liver cirrhosis; Group II: patients with HCC; HCV: hepatitis C virus, HBV: hepatitis B virus, HCC: hepatocellular carcinoma

Table 2. Clinical and Ultrasonographic Characteristics of The Two Patients Groups

\begin{tabular}{|c|c|c|c|c|}
\hline & $\begin{array}{l}\text { Group I, } \\
\text { Liver } \\
\text { cirrhosis } \\
(\text { No. }=20)\end{array}$ & $\begin{array}{c}\text { Group II, } \\
\text { Hepatocellular } \\
\text { carcinoma } \\
(\text { No.=20) }\end{array}$ & $\begin{array}{c}\text { t-test } \\
/ X^{2}\end{array}$ & p-value \\
\hline Portal vein di & VD) $14.1 \pm 1.8$ & $15.8 \pm 1.8$ & 1.32 & 0.32 \\
\hline \multicolumn{5}{|c|}{ Portal vein thrombosis (PVT) } \\
\hline Yes & $3(15 \%)$ & $4(20 \%)$ & \multirow[t]{2}{*}{0.25} & \multirow[t]{2}{*}{0.14} \\
\hline No & $17(85 \%)$ & $16(80 \%)$ & & \\
\hline \multicolumn{5}{|c|}{ Portal vein invasion: } \\
\hline Yes & - & $4(20 \%)$ & \multirow[t]{2}{*}{ - } & \multirow[t]{2}{*}{ - } \\
\hline No & - & $16(80 \%)$ & & \\
\hline \multicolumn{5}{|c|}{ Biliary radical dilatation (IHBRD) } \\
\hline Positive & 20 & 0 & \multirow[t]{2}{*}{40} & \multirow[t]{2}{*}{$0.001 *$} \\
\hline Negative & 0 & 20 & & \\
\hline MELD score & $18.2 \pm 4.9$ & $24.5 \pm 9.7$ & 3.62 & $0.01 *$ \\
\hline \multicolumn{5}{|c|}{ Milan criteria: } \\
\hline Within & - & $9(45 \%)$ & \multirow[t]{2}{*}{-} & \multirow[t]{2}{*}{ 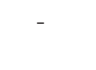 } \\
\hline Beyond & - & $11(55 \%)$ & & \\
\hline Tumor size & $<3 \mathrm{~cm}$ & 8 & \multirow[t]{2}{*}{$8(40 \%)$} & \multirow[t]{2}{*}{-} \\
\hline$\geq 3 \mathrm{~cm}$ & - & $12(60 \%)$ & & \\
\hline \multicolumn{5}{|c|}{ Tumor number } \\
\hline Single & - & $9(45 \%)$ & \multirow[t]{2}{*}{ - } & \multirow[t]{2}{*}{ - } \\
\hline Multiple & - & $11(55 \%)$ & & \\
\hline
\end{tabular}

I: patients with liver cirrhosis; Group II: patients with $\mathrm{HCC} ; \mathrm{M}$

End-Stage Liver Disease score; *Significant $\mathrm{P}$ was considered at $<0.05$ 
Table 3. Statistical Comparison of The Routine Laboratory Findings of The Studied Groups

\begin{tabular}{|c|c|c|c|c|c|c|c|c|}
\hline & \multirow{2}{*}{$\begin{array}{c}\text { Group I } \\
\text { liver cirrhosis }\end{array}$} & \multirow{2}{*}{$\begin{array}{l}\text { Group II } \\
\text { HCC }\end{array}$} & \multirow{2}{*}{$\begin{array}{l}\text { Group III } \\
\text { Control }\end{array}$} & \multicolumn{2}{|c|}{ ANOVA } & \multicolumn{3}{|c|}{ Tukey's test } \\
\hline & & & & F. test & p. value & $\mathrm{P} 1$ & $\mathrm{P} 2$ & P3 \\
\hline Serum Albumin (S. Albumin) & $2.6 \pm 0.3$ & $2.4 \pm 0.2$ & $4.0 \pm 0.2$ & 2.52 & $0.04 *$ & $0.03 *$ & $0.04 *$ & $0.02 *$ \\
\hline Total bilirubin (T. bilirubin) & $2.4 \pm 1.7$ & $1.9 \pm 0.6$ & $0.5 \pm 0.17$ & 2.69 & $0.02 *$ & $0.04 *$ & $0.01 *$ & $0.01 *$ \\
\hline Direct bilirubin & $0.9 \pm 0.7$ & $0.9 \pm 0.3$ & $0.1 \pm 0.06$ & 2.32 & $0.008^{*}$ & $0.04 *$ & $0.01 *$ & $0.001 *$ \\
\hline Alanine amino transferase (ALT) & $34.1 \pm 16.1$ & $37.87 \pm 20.11$ & $22.27 \pm 8.15$ & 5.63 & $0.007 *$ & $0.02 *$ & $0.04 *$ & $0.02 *$ \\
\hline Aspartate amino transferase (AST) & $54.9 \pm 21.7$ & $59.4 \pm 47.4$ & $24.9 \pm 7.0$ & 3.85 & $0.007 *$ & $0.03 *$ & $0.01 *$ & $0.001 *$ \\
\hline International normalized ratio (INR) & $1.3 \pm 0.23$ & $1.9 \pm 0.3$ & $1.00 \pm 0.05$ & 3.63 & $0.019^{*}$ & $0.01 *$ & $0.02 *$ & $0.04 *$ \\
\hline Prothrombin activity & $70.4 \pm 14.9$ & $64.7 \pm 6.1$ & $100.1 \pm 0.08$ & 0.58 & $0.02 *$ & $0.020 *$ & $0.04 *$ & $0.01 *$ \\
\hline Platelets cells & $90074.0 \pm 46203.8$ & $82813.3 \pm 48738.8$ & $199600.0 \pm 56753.6$ & 5.62 & 0.05 & $0.03 *$ & $0.02 *$ & $0.04 *$ \\
\hline Hemoglobin\% & $10.16 \pm 1.5$ & $10.33 \pm 2.1$ & $14.08 \pm 0.9$ & 0.32 & 0.96 & 0.41 & 0.07 & 0.32 \\
\hline Total leucocytic counts (TLC) & $6533.3 \pm 5890.1$ & $7018.6 \pm 5436.3$ & $5660.0 \pm 1545.8$ & 0.75 & 0.14 & 0.65 & 0.09 & 0.52 \\
\hline
\end{tabular}

*Significant P was considered at <0.05; P1 comparison group I vs group II; P2 comparison group I vs group III; P3 comparison group II vs group III.

Table 4. Statistical Comparison of The Levels of AFP, HIF1 $\alpha$, NFKB/p65 Expression and Binding Activities between The Studied Groups

\begin{tabular}{|c|c|c|c|c|c|c|c|c|}
\hline & \multirow{2}{*}{$\begin{array}{c}\text { Group I } \\
\text { liver cirrhosis }\end{array}$} & \multirow{2}{*}{$\begin{array}{l}\text { Group II } \\
\text { HCC }\end{array}$} & \multirow{2}{*}{$\begin{array}{c}\text { Group III } \\
\text { Control } \\
\end{array}$} & \multicolumn{2}{|c|}{ ANOVA } & \multicolumn{3}{|c|}{ Tukey's test } \\
\hline & & & & F. test & p. value & P1 & $\mathrm{P} 2$ & P3 \\
\hline alpha-fetoprotein $(\mathrm{ng} / \mathrm{ml})$ & $27.9 \pm 5.3$ & $654.8 \pm 91.1$ & $2.01 \pm 0.5$ & 9.3 & $0.001 *$ & $0.001 *$ & $0.001 *$ & $0.001 *$ \\
\hline HIF-1 $\alpha(\mu \mathrm{g} / \mathrm{L})$ & $93.1 \pm 13.2$ & $145.9 \pm 24.2$ & $33.7 \pm 4.1$ & 12.3 & $0.001 *$ & $0.001 *$ & $0.001 *$ & $0.001 *$ \\
\hline NFKB/p65 mRNA & $0.099 \pm 0.006$ & $0.18 \pm 0.006$ & $0.023 \pm 0.006$ & 11.3 & $0.001 *$ & $0.002 *$ & $0.001 *$ & $0.003 *$ \\
\hline NFKB/p65 binding & $0.34 \pm 0.04$ & $0.77 \pm 0.05$ & $0.11 \pm 0.02$ & 12.6 & $0.003^{*}$ & $0.001 *$ & $0.001 *$ & $0.001 *$ \\
\hline
\end{tabular}

*P was calculated by one way ANOVA test followed by Tukey's post-hoc test. P was considered significant at $<0.05$; *Significant; P1 comparison between group I and II; P2 comparison between group I and III; P3 comparison between group II and III; HIF-1 1 : hypoxia inducible factor one alpha, NFKB/p65: nuclear factor kappa B/p65 subunit

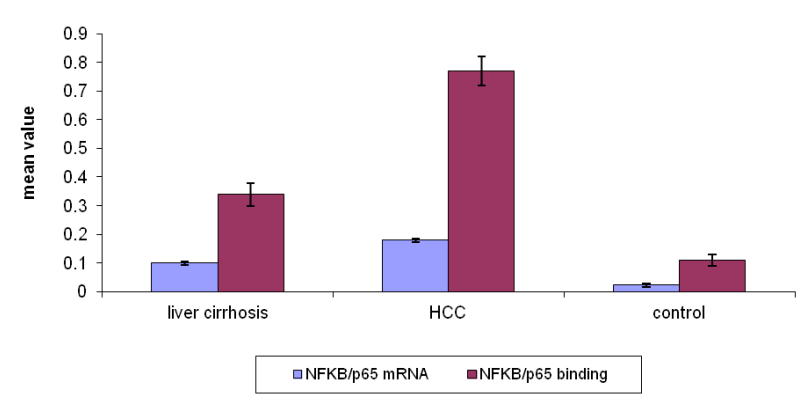

Figure 1. NFKB/P65 mRNA Expression Levels and Binding Activity in The Studied Groups, they were significantly increased in hepatocellular carcinoma group compared to the other groups

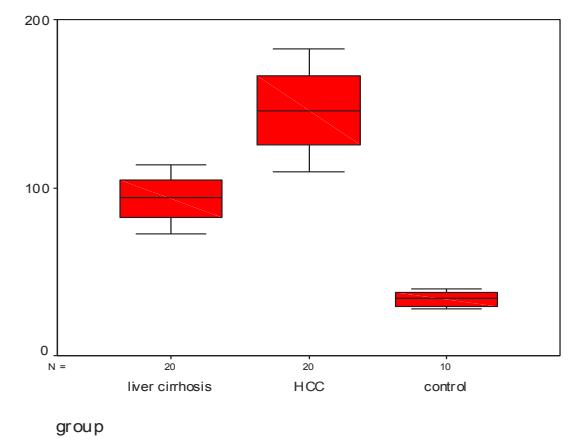

Figure 2. Hyoxia Inducible Factor-1 $\alpha$ Serum Levels in The Studied Groups, showing a significant increase in hepatocellular carcinoma group compared to the other groups

were significantly up regulated in PMNCs from HCC patients $(0.18+0.006)$ compared to those from liver cirrhosis patients $(0.099+0.006)$ or control group $(0.023+0.006)$ with p-value $<0.01$. Moreover, the DNA binding capacity of $\mathrm{NF}-\varkappa \mathrm{B} / \mathrm{p} 65$ subunit in the nuclear fractions of PMNCs was found to be significantly different among the studied group $(\mathrm{p}<0.01)$ (Figure 1 and Table 4). Additionally, serum levels of hypoxia inducible
Table 5. Correlation Matrix between all The Studied Parameters

\begin{tabular}{|c|c|c|c|c|c|c|}
\hline & \multicolumn{2}{|c|}{$\begin{array}{c}\text { Serum } \\
\text { HIF-1 } \alpha, \text { ug/L }\end{array}$} & \multicolumn{2}{|c|}{$\begin{array}{c}\mathrm{NF} x \mathrm{~B} / \\
\text { p65 mRNA }\end{array}$} & \multicolumn{2}{|c|}{$\begin{array}{c}\text { NFKB/ } \\
\text { p65 binding }\end{array}$} \\
\hline & $\mathrm{r}$ & $\mathrm{p}$ & $\mathrm{r}$ & $\mathrm{p}$ & $\mathrm{r}$ & $\mathrm{P}$ \\
\hline Age & -0.087 & 0.296 & -0.163 & 0.126 & 0.015 & 0.017 \\
\hline Sex & 0.017 & 0.205 & 0.276 & 0.596 & -0.038 & 0.41 \\
\hline MELD score & 0.421 & $0.009 *$ & 0.225 & $0.04 *$ & 0.0269 & $0.04 *$ \\
\hline \multicolumn{7}{|c|}{ Portal vein invasion } \\
\hline & 0.425 & $0.01 *$ & 0.523 & $0.04 *$ & 0.285 & $0.04 *$ \\
\hline Tumor size & 0.311 & $0.01 *$ & 0.526 & $0.009 *$ & 0.374 & $0.01 *$ \\
\hline Tumor number & 0.058 & 0.658 & 0.164 & 0.16 & -0.023 & 0.17 \\
\hline \multicolumn{7}{|c|}{ Alpha-fetoprotein (AFP) $\mathrm{ng} / \mathrm{ml}$} \\
\hline & 0.557 & $0.001 *$ & 0.493 & $0.001 *$ & 0.632 & $0.001 *$ \\
\hline HIF- $1 \alpha, u g / L$ & & & 0.547 & $0.001 *$ & 0.68 & $0.001 *$ \\
\hline
\end{tabular}

factor $1 \alpha$ were significantly elevated in HCC patients $(145.9+24.2 \mu \mathrm{g} / \mathrm{L})$ as compared to liver cirrhosis patients $(93.1+13.2 \mu \mathrm{g} / \mathrm{L})$ and the control group $(33.7+4.1 \mu \mathrm{g} / \mathrm{L})$, p-value $<0.01$ (Figure 2 and Table 4).

Using multiple comparisons test (Tukey's test), the above mentioned parameters were markedly higher in HCC group compared to the liver cirrhosis or to the control group; they were also higher in the liver cirrhosis group compared to the control group (p-value $<0.01$ ).

To further define the role of the HIF- $1 \alpha, \mathrm{NF} x \mathrm{~B} / \mathrm{p} 65$ expression and DNA binding activity in the progression of HCC, Pearson correlation test was used to test their correlations with age, sex, serum alpha fetoprotein and other prognostic determinants of HCC in the studied groups. The mRNA expression levels and binding activity of $\mathrm{NF} x \mathrm{~B} / \mathrm{p} 65$ subunit were significantly correlated with serum alpha fetoprotein, MELD score, tumor size, portal vein invasion, but not correlated with age, sex or tumor number as shown in Table 5. On the other hand, serum levels of HIF 1a showed the same pattern of correlation with these prognostic parameters, together with being significantly correlated with NF $x$ B/p65 mRNA expression levels $(\mathrm{r}=0.547, \mathrm{p}<0.01)$. 


\section{Discussion}

Hepatocellular carcinoma (HCC) is the most common form of liver cancer, usually triggered by chronic inflammation (Zekr et al., 2012) and continuous liver injury (Sakurai et al., 2013). It is a highly vascular tumor characterized by fast infiltrating growth, early metastasis, high-grade malignancy (Lee et al., 2014) and poor therapeutic efficacy (Zhou et al., 2012).

The NFxB family of transcription factors has recently been identified as a critical mechanistic link between chronic inflammation and cancer (Hoesel and Schmid, 2013), however its contribution to the molecular pathogenesis of hepatic carcinogenesis is not fully elucidated.

The results of the current study revealed that NFxB/ P65 subunit expression levels were significantly increased in PMNCs of patients with HCC as compared to those with liver cirrhosis and to the control subjects. These findings are in agreement with the study by Zhang et al. (2013) who reported that the mRNA expression level of NFxB/ p65 was significantly increased in human HCC tissues with invasion than that of without invasion, where this overexpression contributed to HCC metastasis through activation of $\mathrm{NF}$ B dependent matrix metaoproteinasse-9 expression. Moreover, Wu et al. (2009) observed that hepatic NFxB mRNA was aberrantly overexpressed during the course of rat hepatocarcinogenesis development.

Regarding the DNA binding capacity of the p65 subunit of NF- $x \mathrm{~B}$, the present study showed it was significantly increased in PMNCs from HCC patients compared to those with liver cirrhosis and to the control subjects. This finding is consistent with the study of Yokoo et al. (2011) who reported constitutive activation of NF- $x \mathrm{~B}$ in human HCC tissue samples compared to surrounding liver tissues.

The viewpoint that NFKB activation has a prominent role in hepatic carcinogenesis was underscored by the study done by $\mathrm{Wu}$ et al. (2010) who proved that small interference RNA ( siRNA) mediated inhibition of nuclear factor- $x \mathrm{~B} / \mathrm{p} 65$ resulted in suppression of human hepatoma cell growth; they also concluded that nuclear factor- $x \mathrm{~B}$ is a potential molecular target for HCC gene therapy. Similarly, Wong et al. (2013) achieved inhibition of growth of liver cancer cells through suppressing the activity of $\mathrm{NF}-\varkappa \mathrm{B}$ by $\mathrm{p} 21$-activated protein kinase 1 -inhibitor. Furthermore, Haruki et al. (2013) showed that inhibition of NF- $\varkappa \mathrm{B}$ enhances the antitumor effect of tumor necrosis factor- $\alpha$ gene therapy for $\mathrm{HCC}$ in mice.

Concomitantly, the finding that NF- $x$ B/p65 was significantly activated in liver cirrhosis patients compared to the control subjects is in harmony with the study by Ren S et al., 2013 who observed that NF- $\chi \mathrm{B} / \mathrm{p} 65$ was activated in macrophages in cirrhotic patients with hypersplenism, as it was found to promote phagocytosis and cytokine secretion by splenic macrophages. Well in line, Li et al. (2012) reported that elevated expression of NF- $x \mathrm{~B} / \mathrm{p} 65$ is closely associated with the occurrence and development of hepatic fibrosis, through increasing secretion of collagens I and III after the activation of hepatic stellate cell.

Taken together, this observed activation of NF- $x \mathrm{~B}$ may be attributed to the fact that HCC commonly arises in a setting of chronic inflammation and subsequent liver fibrosis and cirrhosis (Ramakrishna et al., 2013). It was found that in $\mathrm{HBV}$-induced hepatocarcinogenesis, the oncogenic $\mathrm{HBV} X$ protein activates the NF- $\varkappa \mathrm{B}$ signaling pathway through the upregulation of TANK-binding kinase 1 (TBK1), thus promoting progression of $\mathrm{HCC}$ via proliferative and antiapoptotic effects, as well as triggering the spread of tumor cells (Kim et al., 2010 and Zhang et al., 2010). The same mechanism can be displayed in $\mathrm{HCV}$ induced $\mathrm{HCC}$, where $\mathrm{HCV}$ core protein was found to mediate activation of NF- $x \mathrm{~B}$. Moreover, many patients with advanced liver disease have increased levels of lipopolysaccharides which are known activators for NF$x \mathrm{~B}$ in the liver (Luedde et al., 2011).

It is worth noting that the reported association between overexpression and activation is in accordance with the study of Wang L et al., 2013 who documented an overexpression of $\mathrm{NF} x \mathrm{~B} / \mathrm{p} 65$ in human breast cancer cell line causing increased NF- $x \mathrm{~B}$ transcriptional activity. Consequently, active NF- $x \mathrm{~B}$ signaling can promote cancer progression and metastasis through induction of several chemotactic and anti-apoptotic and cell cycle regulatory genes, controlling epithelial to mesenchymal transition and enhancing tumor vascularization (Xia et al., 2014).

Among the upregulated NF- $\varkappa \mathrm{B}$-responsive genes, hypoxia inducible factor one alpha (HIF-1 $\alpha$ ) is a master regulatory transcription factor controlling cellular adaptation to hypoxia, activating metabolic and signaling pathways promoting cell survival (Lenihan et al., 2013).

The current study reported a significant increase in serum HIF- $1 \alpha$ levels in HCC patients compared to those with liver cirrhosis and control subjects. This finding is in agreement with the study of Li et al. (2011) who concluded that hepatic HIF-1 $\alpha$ expression is associated with the development and prognosis of HCC and proved that circulating HIF-1 $\alpha$ level can be a useful marker for HCC diagnosis and prognosis. Furthermore, these results are in line with the fact that hypoxia is a characteristic feature of solid tumors, where cells respond to hypoxia by generating mature and functional HIF-1 $\alpha$ (Semenza, 2011) which plays a pivotal role in the growth, infiltration and metastasis of tumor cells (Unwith et al.,2014).

Of note, the observed significantly higher levels of circulating HIF- $1 \alpha$ in patients with liver cirrhosis compared to control subjects can be explained on the basis of its role in the hepatic inflammation-fibrosis axis (Rosmorduc et al., 2010). Hypoxic areas represent a major feature of cirrhotic liver where hypoxia inducible factors help to counteract the decrease in oxygen tension through upregulation of angiogenesis and enhancement of liver fibrogenesis (Troeger et al., 2011).

Concerning its relationship with NF- $x \mathrm{~B} / \mathrm{P} 65$, serum HIF- $1 \alpha$ was significantly correlated with nuclear factor$x \mathrm{~B} / \mathrm{P} 65$ expression levels; this finding is in keeping with the notion of an existing crosstalk or interplay between $\mathrm{NF}-\varkappa \mathrm{B}$ and HIF- $1 \alpha$ particularly in carcinogenesis. NF$\chi \mathrm{B}$ is a critical transcriptional activator of HIF- $1 \alpha$ and basal nuclear factor- $\chi \mathrm{B}$ activity is required for HIF- $1 \alpha$ protein accumulation under hypoxia (Taylor et al., 2009). Moreover, a hypoxia-dependent transcriptional 
upregulation of hypoxia-inducible factor- $1 \alpha$ by nuclear factor- $x \mathrm{~B}$ was reported in several types of cancer (Yoshida et al., 2013), stimulating epithelial to mesenchymal transition (Cheng et al., 2014), thus promotinralg tumor growth and angiogenesis.

Furthermore, the present study contributed information towards establishing a significant association of the aberrant activation and over expression of NF- $x \mathrm{~B} / \mathrm{p} 65$ with bad prognostic parameters for HCC as MELD score, tumor size, portal vein invasion, suggesting an important role for $\mathrm{NF}-\varkappa \mathrm{B} / \mathrm{p} 65$ in the progression of $\mathrm{HCC}$ and highlighting its significance as a prognostic marker for HCC. In harmony with this note, are the previous studies which confirmed the prognostic significance of NF- $x \mathrm{~B}$ in various types of cancers such as breast cancer (Sarkar et al., 2013) and squamous cell carcinoma of head and neck (Balermpas et al., 2013).

In conclusion, the current study provided unequivocal evidence that active $\mathrm{NF}-x \mathrm{~B}$ signaling has a major contribution to the molecular pathogenesis of human hepatocellular carcinoma. Besides, the association between NF- $x \mathrm{~B} / \mathrm{p} 65$ activity and expression levels with the bad prognostic parameters for HCC potentiates their value as prognostic markers to predict treatment outcome, metastasis or recurrence. The present study has also shed light on the interplay between NF- $x$ B/p65 and HIF1- $\alpha$ in hepatic carcinogenesis as proved by the impact of $\mathrm{NF}-x \mathrm{~B} / \mathrm{p} 65$ overexpression on the circulating levels of HIF1- $\alpha$. Finally, the activation of NF- $x$ B/p65 in HCC has implicated its pivotal role as a novel potential therapeutic target for treatment of patients with HCC.

\section{References}

Abdelaziz AO, Elbaz TM, Shousha HI, et al (2014). Survival and prognostic factors for hepatocellular carcinoma: an Egyptian multidisciplinary clinic experience. Asian Pac J Cancer Prev, 15, 3915-20.

Balermpas P, Michel Y, Wagenblast J, et al (2013). Nuclear $\mathrm{NF}-x \mathrm{~B}$ expression correlates with outcome among patients with head and neck squamous cell carcinoma treated with primary chemoradiation therapy. Int J Radiat Oncol Biol Phys, 86, 785-90.

Beale G, Chattopadhyay D, Gray J, et al (2008). AFP, PIVKAII, GP3, SCCA-1 and follisatin as surveillance biomarkers for hepatocellular cancer in non-alcoholic and alcoholic fatty liver disease. BMC Cancer, 18, 8-200.

Bradford MM (1976). A rapid and sensitive method for the quantitation of microgram quantities of protein utilizing the principle of protein-dye binding. Anal Biochem, 72, 248-54.

Bruix J, Sherman M (2005). Practice Guidelines Committee, American Association for the Study of Liver Diseases (AASLD). Management of hepatocellular carcinoma. Hepatology, 42, 1208-36.

Cheng ZX, Wang DW, Liu T, et al (2014). Effects of the HIF-1 $\alpha$ and NF- $x \mathrm{~B}$ loop on epithelial-mesenchymal transition and chemoresistance induced by hypoxia in pancreatic cancer cells. Oncol Rep, 31, 1891-8.

Escárcega RO, Fuentes-Alexandro S, García-Carrasco M, Gatica A, Zamora A (2007). The transcription factor nuclear factorkappa B and cancer. Clin Oncol, 19, 154-61.

Gao J, Xie L, Yang WS, et al (2012). Risk factors of hepatocellular carcinoma - current status and perspectives.
Asian Pac J Cancer Prev, 13, 743-52.

Gong JP, Liu CA, Wu CX, et al (2002). Nuclear factor kB activity in patients with acute severe cholangitis. World $J$ Gastroenterol, 8, 346-9.

González-Ramos R, Rocco J, Rojas C, et al (2012). Physiologic activation of nuclear factor kappa-B in the endometrium during the menstrual cycle is altered in endometriosis patients. Fertil Steril, 97, 645-51.

Görlach A, Bonello S (2008). The cross-talk between NF-kappaB and HIF-1: further evidence for a significant liaison. Biochem $J, 412,17-9$.

Haruki K, Shiba H, Fujiwara Y, et al (2013). Inhibition of nuclear factor- $\varkappa \mathrm{B}$ enhances the antitumor effect of tumor necrosis factor- $\alpha$ gene therapy for hepatocellular carcinoma in mice. Surgery, 154, 468-78.

Hoesel B, Schmid JA (2013). The complexity of NF- $x$ B signaling in inflammation and cancer. Mol Cancer, 12, 86 .

Hung CH, Lee CM, Kuo FY, et al (2008). Steatosis correlates with hepatic expression of death receptors and activation of nuclear factor-kappaB in chronic hepatitis C. Liver Int, 28, 339-4.

Johnson PJ (2001). The role of serum alpha-fetoprotein estimation in the diagnosis and management of hepatocellular carcinoma. Clin Liver Dis, 5, 145-59.

Kim HR, Lee SH, Jung G (2010). The hepatitis B viral X protein activates NF-kappaB signaling pathway through the upregulation of TBK1. FEBS Lett, 584, 525-30.

Lee SC, Tan HT, Chung MC (2014). Prognostic biomarkers for prediction of recurrence of hepatocellular carcinoma: Current status and future prospects. World J Gastroenterol, 20, 3112-24.

Lei JY, Wang WT, Yan LN. (2013). Up-to-seven criteria for hepatocellular carcinoma liver transplantation: a single center analysis. World J Gastroenterol, 19, 6077-83.

Lenihan CR, Taylor CT (2013). The impact of hypoxia on cell death pathways. Biochem Soc Trans, 41, 657-63.

Li S, Yao D, Wang L, et al (2011). Expression characteristics of hypoxia-inducible factor- $1 \alpha$ and its clinical values in diagnosis and prognosis of hepatocellular carcinoma. Hepat Mon, 11, 821-8.

Li WW, Wang QC, Song XW, et al (2012). Correlation of the expression of NF- $x \mathrm{~B}$ p65 and hepatic fibrosis in hepatitis patients. Zhonghua Yi Xue Za Zhi, 17, 1886-8.

Luedde T, Schwabe RF (2011). NF- $x$ B in the liver-linking injury, fibrosis and hepatocellular carcinoma. Nat Rev Gastroenterol Hepatol, 8, 108-18.

Mimeault M, Batra SK (2013). Hypoxia-inducing factors as master regulators of stemness properties and altered metabolism of cancer- and metastasis-initiating cells. J Cell Mol Med, 17, 30-54.

Ramakrishna G, Rastogi A, Trehanpati N, et al (2013). From cirrhosis to hepatocellular carcinoma: new molecular insights on inflammation and cellular senescence. Liver Cancer, 2, 367-383.

Ren S, Zhang S, Li M, et al (2013). NF- $\varkappa B / p 65$ and c-Rel subunits promote phagocytosis and cytokine secretion by splenic macrophages in cirrhotic patients with hypersplenism. Int $J$ Biochem Cell Biol, 45, 335-43.

Rosmorduc O, Housset C (2010). Hypoxia: a link between fibrogenesis, angiogenesis and carcinogenesis in liver disease. Semin Liver Dis, 30, 258-70.

Sakurai T, Kudo M (2013). Molecular Link between Liver Fibrosis and Hepatocellular Carcinoma. Liver Cancer, 2, $365-6$.

Sarkar DK, Jana D, Patil PS, et al (2013). Role of NF- $\varkappa$ B as a prognostic marker in breast cancer: a pilot study in Indian patients. Indian J Surg Oncol, 4, 242-7. 
Semenza GL (2013). HIF-1 mediates metabolic responses to intratumoral hypoxia and oncogenic mutations. J Clin Invest, 123, 3664-71.

Su CH, Lin Y, Cai L (2013). Genetic factors, viral infection, other factors and liver cancer: an update on current progress. Asian Pac J Cancer Prev, 14, 4953-60.

Sun W, Guo MM, Han P, et al (2012). Id-1 and the p65 subunit of NF- $x \mathrm{~B}$ promote migration of nasopharyngeal carcinoma cells and are correlated with poor prognosis. Carcinogenesis, 33, 810-7.

Taylor CT, Cummins EP (2009). The role of NF-kappaB in hypoxia-induced gene expression. Ann N Y Acad Sci, 1177, 178-84.

Tiwari M, Mikuni S, Muto H, Kinjo M (2013). Determination of dissociation constant of the NFxB p50/p65 heterodimer using fluorescence cross-correlation spectroscopy in the living cell. Biochem Biophys Res Commun, 5, 430-5.

Troeger JS, Schwabe RF (2011). Hypoxia and hypoxia-inducible factor $1 \alpha$ : potential links between angiogenesis and fibrogenesis in hepatic stellate cells. Liver Int, 31, 143-5.

Unwith S, Zhao H, Hennah L, Ma D (2014). The potential role of $\mathrm{HIF}$ on tumour progression and dissemination. Int J Cancer, doi: 10.1002/ijc.28889.

Van Laere SJ, Van der Auwera I, Van den Eynden GG, et al (2006). Nuclear factor-kappaB signature of inflammatory breast cancer by cDNA microarray validated by quantitative real-time reverse transcription PCR, immuno-histochemistry, and nuclear factor-kappaB DNA-binding. Clin Cancer Res, 12, 3249-56

Van Loo G, Beyaert R. (2011). Negative regulation of NF- $x$ B and its involvement in rheumatoid arthritis. Arthritis Res Ther, 31, 221.

Wang L1, Kang F, Li J, Zhang J, Shan B (2013). Overexpression of p65 attenuates celecoxib-induced cell death in MDAMB-231 human breast cancer cell line. Cancer Cell Int, 13, 14 .

Wilkins T, Malcolm JK, Raina D, et al (2010), Hepatitis C: diagnosis and treatment. American Family Physician, 81, $1351-7$.

Wong LL, Lam IP, Wong TY, et al (2013). IPA-3 inhibits the growth of liver cancer cells by suppressing PAK1 and NF$x \mathrm{~B}$ activation. PLoS One, $\mathbf{8}$, e68843.

Wu W, Yao D, Wang Y, et al (2010). Suppression of human hepatoma (HepG2) cell growth by nuclear factor-kappaB/ p65 specific siRNA. Tumour Biol, 31, 605-11.

Wu W, Yao DF, Qiu LW, et al (2009). Characteristics of hepatic nuclear-transcription factor-kappa $\mathrm{B}$ expression and quantitative analysis in rat hepatocarcinogenesis. Hepatobiliary Pancreat Dis Int, 8, 504-9.

Xia JT, Chen LZ, Jian WH, et al (2014). MicroRNA-362 induces cell proliferation and apoptosis resistance in gastric cancer by activation of NF- $x \mathrm{~B}$ signaling. $J$ Transl Med, 12, 33 .

Yokoo H, Yasuda J, Nakanishi K, et al (2011). Clinicopathological significance of nuclear factor- $x \mathrm{~B}$ activation in hepatocellular carcinoma. Hepatol Res, 41, 240-9.

Yoshida T, Hashimura M, Mastumoto T, et al (2013). Transcriptional upregulation of HIF- $1 \alpha$ by NF- $\chi \mathrm{B} / \mathrm{p} 65$ and its associations with $\beta$-catenin/p300 complexes in endometrial carcinoma cells. Lab Invest, 93, 1184-93.

Zekri AR, Hassan ZK, Bahnassy AA, et al (2012). Molecular prognostic profile of Egyptian HCC cases infected with hepatitis C virus. Asian Pac J Cancer Prev, 13, 5433-8.

Zhang J, Zhang DL, Jiao XL, Dong Q (2013). S100A4 regulates migration and invasion in hepatocellular carcinoma HepG2 cells via NF- $\varkappa$ B-dependent MMP-9 signal. Eur Rev Med Pharmacol Sci, 17, 2372-82.

Zhang F, Wang Q, Ye L, et al (2010). Hepatitis B virus X protein upregulates expression of calpain small subunit 1 via nuclear factor- $x \mathrm{~B} / \mathrm{p} 65$ in hepatoma cells. J Med Virol, 82, 920-8.

Zhou L, Liu C, Meng FD, et al (2012). Long-term prognosis in hepatocellular carcinoma patients after hepatectomy. Asian Pac J Cancer Prev, 13, 483-6. 